\title{
CURRENT VIEW ON VITAMIN K2 ROLE IN DISEASES BASED ON CLINICAL TRIALS
}

\author{
PIOTR JAKUBOWSKI $^{1}{ }^{*}$, ŁUKASZ SMYK $^{1}$, ŁUKASZ PUCHAŁA ${ }^{2}$, JOANNA BIAŁKOWSKA $^{3}$ \\ ${ }^{I}$ Department of Pharmacology and Toxicology, School of Medicine, University of Warmia and Mazury in Olsztyn, 30 \\ Warszawska Street, 11-041 Olsztyn, Poland \\ ${ }^{2}$ Department of Medical Biology, Faculty of Health Sciences, University of Warmia and Mazury in Olsztyn, 14C Żolnierska \\ Street, 10-900 Olsztyn, Poland \\ ${ }^{3}$ Department of Public Health, Faculty of Health Sciences, University of Warmia and Mazury in Olsztyn, 14C Żotnierska \\ Street, 10-900 Olsztyn, Poland
}

*corresponding author: piotr.jakubowski@uwm.edu.pl

Manuscript received: November 2018

\begin{abstract}
Vitamin $\mathrm{K} 2$ is found in fermented foods such as dairy products, natto (fermented soybeans) and some animal products. It has been shown that it can be beneficial in many diseases. Most of the data refer to the use of this vitamin in osteoporosis, for instance, low frequency of hip fractures in Japan is correlated with significant consumption of natto. Also, long-term supplementation of vitamin K2 decreased loss of bone mass in postmenopausal women. Vascular calcification can be prevented by high dietary intake of vitamin K2 and also patients undergoing dialysis may benefit from supplementation. Besides this conditions, vitamin K2 may be applicable in diabetes mellitus type 2, cancer (especially prostate and breast) or multiple sclerosis. The great advantage of this vitamin is its low toxicity and favourable pharmacokinetics.
\end{abstract}

\section{Rezumat}

Vitamina K2 se găsește în alimentele fermentate, cum sunt produsele lactate, natto (soia fermentată) și unele produse de origine animală, demonstrându-se efectul lor benefic în diferite patologii. Cele mai multe studii se referă la utilizarea acestei vitamine în cazurile de osteoporoză, de exemplu, frecvența scăzută a fracturilor de şold în Japonia este corelată cu consumul semnificativ de natto. De asemenea, suplimentarea dietei pe termen lung cu vitamina K2 diminuează pierderea de masă osoasă la femeile aflate în postmenopauză. Creșterea aportului de vitamină K2 din dietă poate preveni calcifierea vasculară şi poate ameliora starea pacienților supuși dializei. Mai mult, vitamina K2 poate fi administrată în diabetul zaharat de tip 2, cancer mamar și de prostată sau scleroză multiplă. Marele avantaj al acestei vitamine este toxicitatea scăzută şi caracteristicile farmacocinetice favorabile.

Keywords: vitamin K2, MK-7, osteoporosis, dietary supplements

\section{Introduction}

Vitamin $\mathrm{K}$ is present in two major forms - vitamin K1 (VK1) (phylloquinone) and vitamin K2 (VK2) (menaquinone). Chemically, the vitamin $\mathrm{K}$ family comprises 2-methyl-1,4-naphthoquinone derivatives. Phylloquinone (PK) has a partially unsaturated side chain formed of one isopentenyl unit followed by three isopentyl units and menaquinones (MK) possess a fully unsaturated side chain. Vitamin K1 function in blood coagulation, bone and vascular metabolism is widely recognized [1], much less is known about the role of vitamin $\mathrm{K} 2$.

VK2 has several subtypes, which differ in isoprenoid chain length. MKs have a varying number of isoprenoid residues in their side chains. The most important form of VK2 are MKs with four (MK-4) and seven (MK7) isoprenoid residues. They are synthesized by gut bacteria and are found in fermented foods such as dairy products, or natto (fermented soybeans) and also some animal products (e.g. liver, egg yolk, meat).
Recent data suggest, that this are rather bacteria than food, which are responsible for VK2 concentration in blood [2], whereas vitamin D3 concentration depends mainly on food intake [3]. The richest food source of MK-4 is goose liver paste $(369 \mu \mathrm{g} / 100 \mathrm{~g})$ and of MK-7 is the Japanese food, natto, which is produced by Bacillus subtilis, a bacterium that converts VK1 to MK-7. The average concentration of MK-7 in natto is around $1000 \mu \mathrm{g} / 100 \mathrm{~g}$ [4]. Schurgers and Vermeer investigated the pharmacokinetics of MK-7 after ingestion of $200 \mathrm{~g}$ of natto $(3.1 \mu \mathrm{mol}$ of MK-7): MK-7 from natto was absorbed extremely well and $\mathrm{C}_{\max }$ was around $75 \mathrm{nmol} / \mathrm{L}$, followed by a rapid disappearance. MK-7 showed complex pharmacokinetics, with slow disappearance during the second part of the concentration - time curve, while it remained detectable for at least $72 \mathrm{~h} \mathrm{[4].}$

Pharmacokinetics of MK-7 following a single intake from various formulations (oil-based capsules and powder-based tablets) was studied in four intervention 
FARMACIA, 2019, Vol. 67, 4

trials. Tablets showed a slower absorption of MK-7 (time-to-peak) than capsules: $6 \mathrm{~h}$ as compared to $2-4 \mathrm{~h}$, respectively. After the single-dose intake of MK-7 within the dose range between 75 and $360 \mu \mathrm{g}$ /day, linear $24 \mathrm{~h}$ dose-response relationship was found [5]. Toxicological studies in mice and rats indicate that MK-7 synthetic form is very safe: neither a single oral dose of $2000 \mathrm{mg} / \mathrm{kg}$ body weight (b.w.) nor $10 \mathrm{mg} / \mathrm{kg}$ b.w. for 90 days caused any toxic effects [6]. Earlier studies in human healthy volunteers demonstrated that MK-7 (single doses of up to $1320 \mu \mathrm{g}$ of MK-7/ person) has no effect on the clotting cascade in healthy individuals. Also, no effects on coagulation were observed in a double-blinded, randomized, placebocontrolled study in healthy prepubertal children following a daily intake of $45 \mu \mathrm{g}$ of natto-derived MK-7 for 8 weeks [7].

VK2 is a cofactor for $\gamma$-glutamylcarboxylase, which $\gamma$-carboxylates certain glutamic acid residues in many VK-dependent proteins (VKDP). This reaction allows VKDPs to bind calcium. The VKDPs include a number of clotting factors involved in the coagulation cascade (Factors II, VII, IX, X), circulating anticoagulants (proteins $\mathrm{C}, \mathrm{S}$ and $\mathrm{Z}$ ) and proteins involved in bone and soft-tissue mineralization, like osteocalcin (OC) and matrix GLA protein (MGP). VK2 is required for the activity of coagulation and anticoagulation factors and is generally considered to be required for the function of MGP [8]. VK2 may also act as ligand of the nuclear, steroid, xenobiotic and pregnane $\mathrm{X}$ receptor (PXR). It has been discovered that VK2 mechanism of action is mediated by transcriptional regulation of SXR/PXR target genes receptor, which may be responsible for beneficial effects of VK2 especially in osteoporosis treatment [9].

VK2 is becoming increasingly important in the treatment of many disorders. Whereas to our best knowledge, it has not been approved as a sole treatment for any disease, scientific evidences suggest that it may be useful in many disorders. The aim of this article is to review the pleiotropic effects of VK2 on osteoporosis, vascular calcification and chronic kidney disease (CKD). Moreover, this article summarizes the present and possible future of VK2 use in such conditions as diabetes mellitus, multiple sclerosis and cancer.

\section{Function of VK2 in the pathogenesis and treatment of osteoporosis}

The connection between VK2 and osteoporosis comes from observational studies in postmenopausal women in Japan, where the incidence of hip fracture is lower than in European countries or the United States. Two populations of Japanese women (from Tokyo and Hiroshima regions) and a group of women from United Kingdom were compared. The highest MK-7 concentration was registered in women from Tokyo (average $5.268 \mathrm{ng} / \mathrm{mL}$ ), which was significantly higher than the concentration in the groups in Hiroshima $(1.22 \mathrm{ng} / \mathrm{mL})$ or the United Kingdom $(0.37 \mathrm{ng} / \mathrm{mL})$. MK-7 concentration correlated with the frequency of natto consumption. Hip fraction frequency was significantly lower in the Tokyo group in comparison with Hiroshima group [10]. A later study showed that habitual natto intake was also associated with reduced bone loss at the femoral neck level $\left(-0.5 \mathrm{~g} / \mathrm{cm}^{2}\right.$ in natto group $v s-1.6 \mathrm{~g} / \mathrm{cm}^{2}$ in control group) and at the distal third of the radius $\left(-0.3 \mathrm{~g} / \mathrm{cm}^{2}\right.$ in natto group $v s-1.4 \mathrm{~g} /$ $\mathrm{cm}^{2}$ in control group) in postmenopausal women after 3 years of follow-up. Additionally, it was suggested that not only VK2 but also high concentration of isoflavones in natto may decrease BMD loss [11].

Emaus et al. published results of 1 year randomized double blind placebo controlled study with 334 early menopausal healthy women. The patients received either MK 7 (360 $\mu \mathrm{g} /$ day $)$ or placebo. The results of this trial yielded the following results: in the MK 7 group, serum undercarboxylated osteocalcin (ucOC) was significantly reduced and carboxylated osteocalcin (c OC) was significantly increased (from 13.5 to 19.1 $\mathrm{ng} / \mathrm{mL}$, respectively). However, no statistical difference in bone loss rate between the groups was observed. Authors suggested that this was most probably caused by the relatively short ( 1 year) treatment with MK 7 [12]. 3-year supplementation of low-dose VK2 MK-7 (180 $\mu \mathrm{g}$ MK-7/day which is equivalent of around $20 \mathrm{~g}$ of natto) significantly decreased the age-related loss in bone mass among healthy postmenopausal women. Volunteers taking the MK-7 supplements showed a 3 -year preservation of lumbar spine bone mineral density (BMD), while the expected age related decline in BMD was observed in the placebo group. Both intervention groups experienced bone loss at the site of the femoral neck but MK-7 intake slowed down the progress of this process (difference became only significant after 3 years of supplementation). After adjusting for age and BMI, the beneficial effect of MK7 on BMC remained significant $(p=0.042)$, whereas the effect on BMD became borderline significant $(\mathrm{p}=$ 0.070) [13].

The effect of MK-4 was also studied in postmenopausal women. The drug was administered at a dose of $45 \mathrm{mg}$ / day for 3 years. It was found that it helped to maintain the bone strength at the site of the femoral neck in postmenopausal women by improving bone mineral content (BMC) and femoral neck width (FNW). After adjusting for age and BMI, the beneficial effect of MK7 on BMC remained significant $(\mathrm{p}=0.042)$, whereas the effect on BMD became borderline significant [14]. Jiang et al. compared the efficacy of MK-4 (45 mg/ day) to active metabolite of vitamin D - alfacalcidol $(0.5 \mu \mathrm{g} /$ day $)$ in Chinese postmenopausal women during 1 year study. Both treatments yielded similar results and it was therefore concluded, that MK 4 is an 
effective and safe choice in the treatment of postmenopausal osteoporosis in Chinese women [15]. Nowadays, bisphosphonates and vitamin D are the most used treatments of osteoporosis. The combination therapy with bisphosphonate minodronate $(50 \mathrm{mg} /$ day) and VK2 MK-4 (45 mg/day) was applied in elderly patients (mean age 71.6 years) for 12 months. This treatment showed additive effects in decreasing the levels of bone turnover markers and increased bone mineral density compared with minodronate monotherapy. The most effective was the combination which utilized additionally vitamin D analogue eldecalcitol $(0.75 \mu \mathrm{g} /$ day) [16]. The effectiveness of VK2 MK-4 (45 $\mathrm{mg}$ /day) was also evaluated on osteoporosis in adults with cerebral palsy and high serum concentrations of ucOC. Positive effect on BMD was observed and it was concluded that VK2 might be useful as a first line treatment in this population [17]. Also, a metaanalysis conducted by Huang et al. supports the hypothesis that VK2 plays a role in the maintenance and improvement of vertebral BMD and the prevention of fractures in postmenopausal women with osteoporosis. The results of this meta-analysis showed that VK2 was effective in maintaining the vertebral BMD and forearm BMD in postmenopausal women with osteoporosis, but it did not improve vertebral, hip and forearm BMD. There was also registered a significant decrease of ucOC and increase of OC, which suggests a positive effect for the bone metabolism [18]. MK-7 efficacy was also evaluated in rheumatoid arthritis (RA). It was found that MK-7 at a dose of $100 \mu \mathrm{g} /$ day (as an additive to standard treatment) significantly lowered serum levels of ucOC, C-reactive protein, erythrocyte sedimentation rate and matrix metalloproteinase which suggests that MK-7can improve conditions in RA patients [19].

\section{VK2 and vascular calcification}

Vascular calcification is associated with many diseases. Patients suffering from familial hypocholesteraemia, renal disease and diabetes are especially vulnerable to vascular calcification [8]. Common molecular and cellular mechanisms of bone metabolism and vascular biology, which relate to the osteoporosis and arterial calcification syndrome, were identified. One of the key proteins responsible for this process is MGP, which is a VK-dependent inhibitor of calcification [20]. VK carboxylates MGP and causes its activation. Because MGP is a peripheral protein, VK2 (the most prevalent form of VK in non-hepatic tissue) is the vitamin mostly available to carboxylate MGP [8].

A study conducted among 564 postmenopausal healthy women showed that high dietary intake of VK2 is associated with reduced coronary calcification.

Interestingly, PK intake was not associated with coronary calcification [21]. Similar studies were conducted among patients with peripheral arterial disease (PAD). MKs intake was associated with a reduced risk of this disease especially in patients with hypertension. Contrary, high PK intake does not seem to be associated with reduced PAD risk [22]. MK-7 supplementation ( $360 \mu \mathrm{g}$ once daily) proved to be also effective in the improvement of arterial stiffness among patients who received renal transplant. Subclinical VK deficiency (measured by desphospho-uncarboxylated matrix Gla protein (dp-ucMGP) which is a biomarker of VK status), was prevalent at baseline in 32 patients $(53.3 \%)$ but decreased to $13.3 \%$ after 8 weeks of supplementation [23]. Recently, it has been observed that patients with small intestinal bacterial overgrowth had a higher concentration of dp-ucMGP which indicates a low level of VK2. This phenomenon correlated directly with pulse-wave velocity, which suggests arterial stiffening [2].

Aortic calcification occurs often during the treatment with anticoagulant drugs such as warfarin, which specifically blocks VK-epoxide reductase, causing depletion of the available VK stores and synthesis of noncarboxylated, inactive Gla proteins. It has been proven that diets containing high concentration of VK1 or VK2 (MK4) can reverse aortic calcification induced by warfarin administration in rats [24].

The protective effect of dietary MKs intake against coronary heart disease (CHD) in older men and women was also described in The Rotterdam Study. MK intake (evaluated by food questionnaire) showed no significant association with moderate calcification but in a case of severe calcification a strong inverse relationship was observed [25]. Also another big study (ProspectEPIC), which included over 16.000 postmenopausal women, indicated that a higher dietary intake of VK2 was significantly associated with a lower incidence of CHD [26].

Currently, there is a new clinical trial starting, which will examine the effect of MK-7 supplementation (720 $\mu \mathrm{g} /$ day) on progression of aortic valve calcification. Authors hypothesize that this supplementation will slow down the calcification process [27].

\section{VK2 effects in chronic kidney disease}

Patients with CKD (stages G3-G5) are at particular risk of VK deficiency. A direct connection of this deficiency with impaired protein function responsible for calcium metabolism in the body is suggested by many research studies $[20,24]$. In the case of VK2 deficiency, the activation of the MGP protein is impaired; resulting in the accumulation of calcium ions in the cells and this promotes calcification of the vascular endothelium [28]. Research on rat models suggests that CKD may alter tissue levels of VK1 (lower levels were detected in the liver and heart) and VK2 MK-4 (higher levels of MK-4 were detected in the kidneys) [29]. Reports on the effectiveness of VK2 supplementation in the group of patients with 
CKD are contradictory. Some of the works suggest that it reduces the process of atherosclerosis in blood vessels, but does not affect the progression of calcification. On the other hand, VK2 supplementation significantly reduces the concentration of calcification modulators, i.e. dp-ucMGP, OC and osteoprotegerin [30]. Another study investigating the relationship between VK supplementation (described collectively as $\mathrm{K} 1$ and $\mathrm{K} 2$ ) and the concentration of proteins modulating the calcification process does not confirm this relationship. An important limitation, indicated by the authors, was the lack of a proper method to assess the concentration and amount of VK2 ingested by each meal in the examined groups of patients [31]. A recent study suggests that circulating dp-ucMGP is associated with kidney dysfunction and arterial stiffness which may support the hypothesis about the usefulness of VK2 in patients receiving dialysis treatment [32]. It has been proven that daily supplementation of haemodialysis patients with 360 $\mu \mathrm{g}$ of MK-7 for 28 days, decreased the dp-ucMGP concentration by $86 \%$ after 4 weeks [33].

VK antagonists, such as warfarin, may lead to many adverse effects such as vascular calcification, bone fractures and calciphylaxis among patients with CKD [34]. Currently, a clinical trial is being conducted which investigates the effect of VK2 MK-7 supplementation $(2000 \mu \mathrm{g} / 3$ times per week) on progression of vascular calcification among CKD patients on chronic haemodialysis with non-valvular atrial fibrillation who are treated with VK antagonists [35].

\section{VK2 and cancer}

Prostate cancer (PC) is one of the most common malignancies in men and the second leading cause of cancer mortality in the United States. In the study conducted by Nimptsch et al. a significant inverse association between advanced prostate cancer and VK2 consumption was observed. MKs from dairy products exhibited a stronger inverse association with advanced prostate cancer incidence than MKs from meat products. Authors concluded that MKs play rather a role in tumour promotion and progression than in tumour initiation [36]. These results are supported by a recent study which proved that VK2 displays anticancer properties in castration-resistant prostate cancer cell line. It was shown, that VK2 suppresses colony formation, inhibits 3D spheroid growth, suppresses cell migration, induces cellular senescence, apoptosis, production of reactive oxygen species and causes cell cycle arrest [37].

Anti-tumour effects were also proven for MK-4 against breast cancer cells. The proposed mechanisms for the anticancer activity of VK2 include induction of both caspase-dependent and independent apoptosis, generation of reactive oxygen species, cell cycle arrest and differentiation [38]. MK-4 chemo-preventive efficacy in patients with hepatocellular carcinoma (HCC) after curative hepatic resection or local ablation was evaluated by Zhong et al. A meta-analysis of six randomized clinical trials and one cohort study (all from Japan) proved that MK-4 may reduce the recurrence rate after 1 year and improve the overall survival [39].

\section{VK2 and multiple sclerosis}

Multiple sclerosis (MS) is one of the most common disabling neurological disorders in young and middleaged adults. The aetiology of this disease is connected with inflammation and VK2 may probably modulate this process. Lasemi et al. determined (by means of ELISA) VK2 serum concentration and found that it was three-fold higher in healthy controls as compared to MS patients. The increasing number of attacks per year and also blurred vision were associated with reduced VK2 serum levels [40]. Earlier, Moriya et al. showed that VK2 MK-4 attenuates the clinical severity of experimental autoimmune encephalomyelitis (animal model of MS) in a prophylactic manner. VK2 reduced the infiltration of inflammatory cells into the spinal cord, expression of MHC class II and inhibition of iNOS in glial cells [41].

\section{VK2 and diabetes mellitus}

VK2 may be also effective in managing diabetes mellitus type 2. Dietary PK and MK intake was analysed by using a food-frequency questionnaire by Beulens et al. Results suggest that VK2 intake tended to be moderately inversely associated with the risk of diabetes [42]. VK2 MK-4 supplementation (30 mg t.i.d.; 4 weeks) among healthy young men $(\mathrm{n}=42)$ was also found to be associated with increased insulin sensitivity index and disposition index. Treatment with VK2 decreased ucOC and increased cOC which suggests a beneficial role of VK2 in increasing insulin sensitivity via the carboxylation of osteocalcin [43]. Other possible mechanisms responsible for antidiabetic function of VK2 are connected with adinopectin, whose level was found to be decreased in obese patients [44]. It has been also demonstrated that VK2 suppresses inflammatory responses via the inactivation of the NF-kappaB signalling pathway and this may be also responsible for the improvement of insulin resistance [45].

\section{Conclusions}

Numerous studies have demonstrated the importance of VK2 in many functions in organism. MK-4 and MK-7 can improve bone status by increasing bone mass and reducing bone loss. The combination of MKs and vitamin D3 or its analogues sustain lumbar BMD and prevent osteoporotic vertebral fractures in postmenopausal women with osteoporosis. VK2 prevents also vascular calcification and can be used in patients 
FARMACIA, 2019, Vol. 67, 4

suffering from vascular calcification or undergoing chronic haemodialysis. Besides this relatively well proven indications, VK2 can be useful in diabetes mellitus type 2, cancer (especially prostate and breast) or multiple sclerosis. Another advantage of VK2 is a very low toxicity which makes it a promising drug in many diseases. Ongoing clinical trials should give the final answer about the efficacy of VK2 in the treatment of various diseases.

\section{References}

1. Basset GJ, Latimer S, Fatihi A, Soubeyrand EBA, Phylloquinone (Vitamin K1): Occurrence, Biosynthesis and Functions. Mini Rev Med Chem., 2017; 17: 10281038.

2. Ponziani FR, Pompili M, Di Stasio E, Zocco MA, Gasbarrini A, Subclinical atherosclerosis is linked to small intestinal bacterial overgrowth via vitamin K2dependent mechanisms. World J Gastroenterol., 2017; 23: 1241-1249.

3. Grigorie D, Coles D, Caragheorgheopol A, Şucaliuc A, Vitamin D Status And consequences of long term supplementation with oral native vitamin D3 on the severity of primary hyperparathyroidism-The Romanian experience. Farmacia, 2018; 66(5): 877-882.

4. Schurgers LJ, Vermeer C, Determination of Phylloquinone and Menaquinones in Food. Pathophysiol Haemost Thromb., 2000; 30: 298-307.

5. Knapen MHJ, Vermeer C, Braam LATE, Pharmacokinetics of menaquinone-7 (vitamin K2) in healthy volunteers. J Clin Trials, 2014; 04: 2-7.

6. Pucaj K, Rasmussen H, Møller M, Preston T, Safety and toxicological evaluation of a synthetic vitamin $\mathrm{K} 2$, menaquinone-7. Toxicol Mech Methods, 2011; 21: 520-532.

7. Van Summeren MJH, Braam LAJLM, Lilien MR, Schurgers LJ, Kuis W, The effect of menaquinone-7 (vitamin K2) supplementation on osteocalcin carboxylation in healthy prepubertal children. Br J Nutr., 2009; 102: 1171-1178.

8. El Asmar MS, Naoum JJ, Arbid EJ, Vitamin K dependent proteins and the role of vitamin $\mathrm{K} 2$ in the modulation of vascular calcification: A review. Oman Med J., 2014; 29: 172-177.

9. Azuma K, Ouchi Y, Inoue S, Vitamin K: Novel molecular mechanisms of action and its roles in osteoporosis. Geriatr Gerontol Int., 2014; 14: 1-7.

10. Kaneki M, Hedges SJ, Hosoi T, Fujiwara S, Lyons A, Crean SJ, Ishida N, Nakagawa M, Takechi M, Sano Y, Mizuno Y, Hoshino S, Miyao M, Inoue S, Horiki K, Shiraki M, Ouchi Y, Orimo H, Japanese fermented soybean food as the major determinant of the large geographic difference in circulating levels of vitamin K2: Possible implications for hip-fracture risk. Nutrition, 2001; 17: 315-321.

11. Ikeda Y, Iki M, Morita A, Kajita E, Kagamimori S, Kagawa Y, Yoneshima H, Intake of fermented soybeans, natto, is associated with reduced bone loss in postmenopausal women: Japanese Population-Based Osteoporosis (JPOS) Study. J Nutr., 2006; 136: 13231328.
12. Emaus N, Gjesdal CG, Almås B, Christensen M, Grimsgaard AS, Berntsen GK, Salomonsen L, Fønnebø $\mathrm{V}$, Vitamin K2 supplementation does not influence bone loss in early menopausal women: A randomised doubleblind placebo-controlled trial. Osteoporos Int., 2010; 21: 1731-1740.

13. Knapen MHJ, Drummen NE, Smit E, Vermeer C, Theuwissen E, Three-year low-dose menaquinone-7 supplementation helps decrease bone loss in healthy postmenopausal women. Osteoporos Int., 2013; 24: 2499-2507.

14. Knapen MHJ, Schurgers LJ, Vermeer C, Vitamin K2 supplementation improves hip bone geometry and bone strength indices in postmenopausal women. Osteoporos Int., 2007; 18: 963-972.

15. Jiang Y, Zhang ZL, Zhang ZL, Zhu HM, Wu YY, Cheng Q, Wu FL, Xing XP, Liu JL, Yu W, Meng XW, Menatetrenone versus alfacalcidol in the treatment of Chinese postmenopausal women with osteoporosis: dummy, positive drug-controlled clinical trial. Clin Interv Aging, 2014; 9: 121-127.

16. Ebina K, Noguchi T, Hirao M, Kaneshiro S, Tsukamoto $\mathrm{Y}$, Yoshikawa H, Comparison of the effects of 12 months of monthly minodronate monotherapy and monthly minodronate combination therapy with vitamin $\mathrm{K} 2$ or eldecalcitol in patients with primary osteoporosis. J Bone Miner Metab., 2016; 34: 243-250.

17. Kodama Y, Okamoto Y, Kubota T, Hiroyama Y, Fukami $\mathrm{H}$, Matsushita K, Kawano Y, Effectiveness of vitamin $\mathrm{K} 2$ on osteoporosis in adults with cerebral palsy. Brain Dev., 2017; 39: 846-850.

18. Huang ZB, Wan SL, Lu YJ, Ning L, Liu C, Fan SW, Does vitamin $\mathrm{K} 2$ play a role in the prevention and treatment of osteoporosis for postmenopausal women: a meta-analysis of randomized controlled trials. Osteoporos Int., 2014; 26: 1175-1186.

19. Abdel-Rahman MS, Alkady EAM, Ahmed S, Menaquinone-7 as a novel pharmacological therapy in the treatment of rheumatoid arthritis: A clinical study. Eur J Pharmacol., 2015; 761: 273-278.

20. Hofbauer LC, Brueck CC, Shanahan CM, Schoppet M, Vascular calcification and osteoporosis - From clinical observation towards molecular understanding. Osteopor Int., 2007; 18: 251-259.

21. Beulens JWJ, Bots ML, Atsma F, Bartelink ML, Prokop M, Geleijnse JM, Witteman JC, Grobbee DE, van der Schouw YT, High dietary menaquinone intake is associated with reduced coronary calcification. Atherosclerosis, 2009; 203: 489-493.

22. Vissers LET, Dalmeijer GW, Boer JMA, Verschuren WMM, van der Schouw YT, Beulens JWJ, The relationship between vitamin $\mathrm{K}$ and peripheral arterial disease. Atherosclerosis, 2016; 252: 15-20.

23. Mansour AG, Hariri E, Daaboul Y, Korjian S, El Alam A, Protogerou AD, Kilany H, Karam A, Stephan A, Bahous SA, Vitamin K2 supplementation and arterial stiffness among renal transplant recipients - a singlearm, single-center clinical trial. J Am Soc Hypertens., 2017; 11: 589-597.

24. Schurgers LJ, Spronk HMH, Soute BA, Schiffers PM, DeMey JG, Regression of warfarin-induced medial elastocalcinosis by high intake of vitamin $\mathrm{K}$ in rats. Blood, 2007; 109: 2823-2831. 
FARMACIA, 2019, Vol. 67, 4

25. Geleijnse JM, Vermeer C, Grobbee DE, Schurgers LJ, Knapen MH, van der Meer IM, Hofman A, Witteman JC, Dietary intake of menaquinone is associated with a reduced risk of coronary heart disease: The Rotterdam Study. J Nutr., 2004; 134: 3100-3105.

26. Gast GCM, de Roos NM, Sluijs I, Bots ML, Beulens JW, Geleijnse JM, Witteman JC, Grobbee DE, Peeters $\mathrm{PH}$, van der Schouw YT, A high menaquinone intake reduces the incidence of coronary heart disease. Nutr Metab Cardiovasc Dis., 2009; 19: 504-510.

27. Lindholt JS, Frandsen NE, Fredgart MH, Øvrehus KA, Dahl JS, Møller JE, Folkestad L, Urbonaviciene G, Becker SW, Lambrechtsen J, Auscher S, Hosbond S, Alan DH, Rasmussen LM, Gerke O, Mickley H, Effects of menaquinone-7 supplementation in patients with aortic valve calcification: study protocol for a randomised controlled trial. BMJ Open, 2018; 8: e022019: 1-7.

28. Wyskida K, Żak-Gołąb A, Łabuzek K, Suchy D, Ficek R, Pośpiech K, Olszanecka-Glinianowicz M, Okopień B, Więcek A, Daily intake and serum concentration of menaquinone-4 (MK-4) in haemodialysis patients with chronic kidney disease. Clin Biochem., 2015; 48: 1246-1251.

29. Turner ME, Adams MA, Holden RM, The Vitamin $\mathrm{K}$ Metabolome in chronic kidney disease. Nutrients, 2018; 10: 1-9.

30. Kurnatowska I, Grzelak P, Masajtis-Zagajewska A, Kaczmarska M, Stefańczyk L, Vermeer C, Maresz K, Nowicki M, Effect of vitamin K2 on progression of atherosclerosis and vascular calcification in nondialyzed patients with chronic kidney disease stage 3-5. Pol Arch Med Wewn., 2015; 125: 631-640.

31. Wyskida K, Żak-Gołąb A, Wajda J, Klein D, Witkowicz J, Ficek R, Rotkegel S, Spiechowicz U, Kocemba Dyczek J, Ciepał J, Olszanecka-Glinianowicz M, Więcek A, Chudek J, Functional deficiency of vitamin $\mathrm{K}$ in hemodialysis patients in Upper Silesia in Poland. Int Urol Nephrol., 2016; 48: 765-771.

32. Puzantian H, Akers SR, Oldland G, Javaid K, Miller R, Ge Y, Ansari B, Lee J, Suri A, Hasmath Z, Townsend R CJ, Circulating dephospho-uncarboxylated matrix Gla-protein is associated with kidney dysfunction and arterial stiffness. Am J Hypertens., 2018; 31: 988-994.

33. Aoun M, Makki M, Azar H, Matta H, Chelala DN, High dephosphorylated-uncarboxylated MGP in hemodialysis patients: risk factors and response to vitamin K2, A pre-post intervention clinical trial. BMC Nephrol., 2017; 18: 1-10.

34. Cozzolino M, Mangano M, Galassi A, Ciceri P, Messa $\mathrm{P}$, Nigwekar S, Vitamin K in Chronic Kidney Disease. Nutrients, 2019; 11: 1-11.
35. Caluwé R, Pyfferoen L, De Boeck K, De Vriese AS, The effects of Vitamin K supplementation and Vitamin $\mathrm{K}$ antagonists on progression of vascular calcification: Ongoing randomized controlled trials. Clin Kidney J., 2016; 9: 273-279.

36. Nimptsch K, Rohrmann S, Linseisen J, Dietary intake of vitamin $\mathrm{K}$ and risk of prostate cancer in the Heidelberg cohort of the European Prospective Investigation into Cancer and Nutrition (EPICHeidelberg). Am J Clin Nutr., 2008; 87: 985-992.

37. Dasari S, Samy ALPA, Kajdacsy-Balla A, Bosland $\mathrm{MC}$, Munirathinam G, Vitamin K2, a menaquinone present in dairy products targets castration-resistant prostate cancer cell-line by activating apoptosis signaling. Food Chem Toxicol., 2018; 115: 218-227.

38. Kiely M, Hodgins SJ, Merrigan BA, Tormey S, Kiely PA, O'Connor EM, Real-time cell analysis of the inhibitory effect of vitamin K2 on adhesion and proliferation of breast cancer cells. Nutr Res., 2015; 35: 736-743.

39. Zhong JH, Mo XS, Xiang B De, Yuan WP, Jiang JF, Xie GS, Li LQ, Postoperative use of the chemopreventive vitamin $\mathrm{K} 2$ analog in patients with hepatocellular carcinoma. PLoS One, 2013; 8: 1-8.

40. Lasemi R, Kundi M, Moghadam NB, Moshammer H, Hainfellner JA, Vitamin K2 in multiple sclerosis patients. Wien Klin Wochenschr., 2018; 130: 307-313.

41. Moriya M, Nakatsuji Y, Okuno T, Hamasaki T, Sawada M, Sakoda S, Vitamin K2 ameliorates experimental autoimmune encephalomyelitis in Lewis rats. $J$ Neuroimmunol., 2005; 170: 11-20.

42. Beulens JW, van der A DL, Grobbee DE, Sluijs I, Spijkerman AM, van der Schouw YT, Dietary phylloquinone and menaquinones intake and risk of type 2 diabetes. Diabetes Care, 2010; 33: 1699-1705.

43. Choi HJ, Yu J, Choi H, An JH, Kim SW, Park KS, Jang HC, Vitamin K2 supplementation improves insulin sensitivity via osteocalcin metaboolism: a placebocontrolled trial. Diabetes Care, 2011; 34: e147.

44. Tschritter O, Fritsche A, Thamer C, Haap M, Rahe S, Staiger H, Maerker E, Häring H, Stumvoll M, Plasma adiponectin concentrations predict insulin sensitivity of both glucose and lipid metabolism 1. Diabetes, 2003; 52: 239-243.

45. Ohsaki Y, Shirakawa H, Miura A, Giriwono PE, Sato S, Ohashi A, Iribe M, Goto T, Komai M, Vitamin K suppresses the lipopolysaccharide-induced expression of inflammatory cytokines in cultured macrophagelike cells via the inhibition of the activation of nuclear factor $\alpha \mathrm{B}$ through the repression of IKK $\alpha / \beta$ phosphorylation. J Nutr Biochem., 2010; 21: 1120-1126. 